\title{
Bodies in Confined Sites, or, 'When You Go Out, Let Them Know That We Are Not Monsters'
}

Ariadne Mikou, University of Roehampton

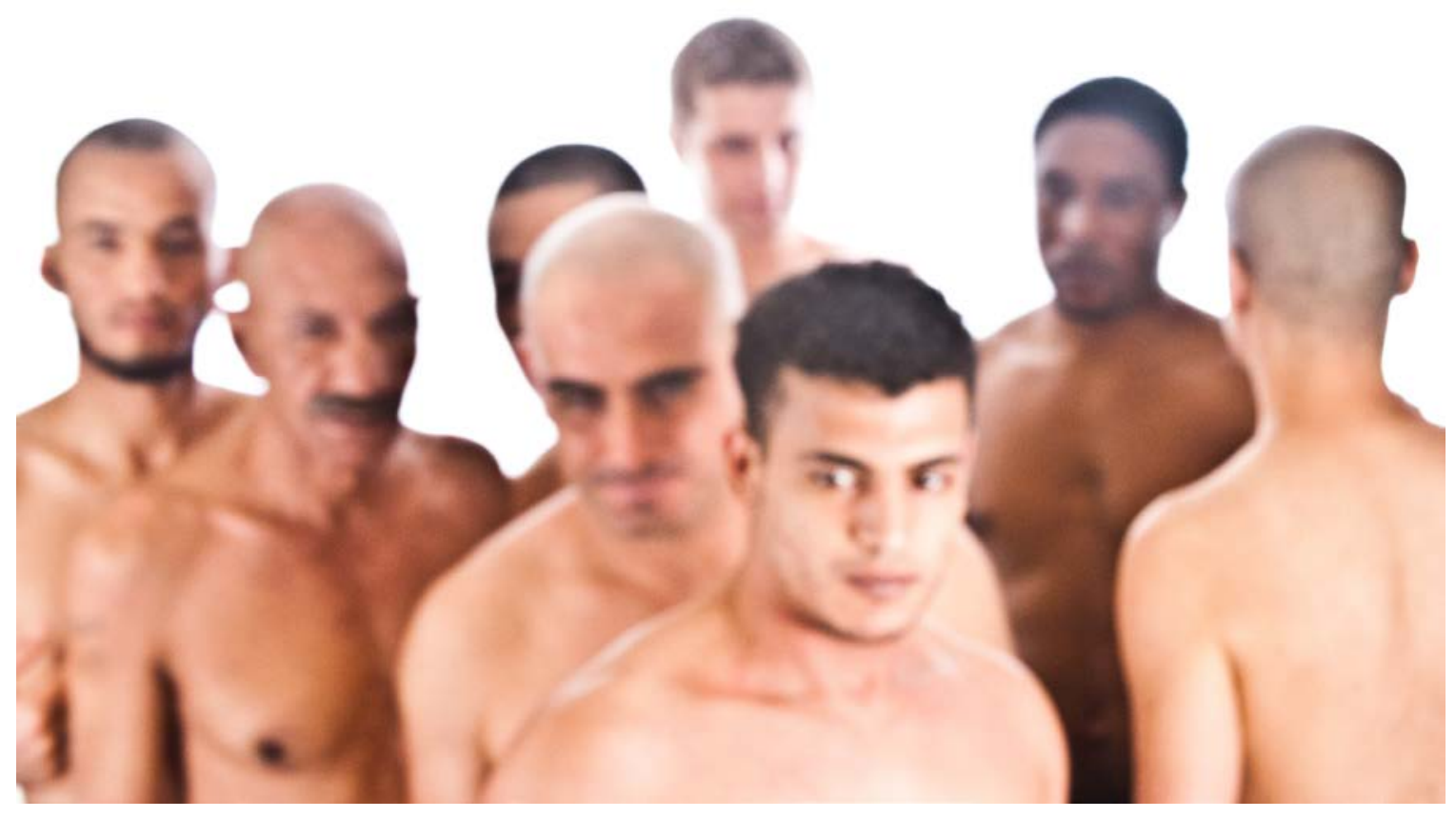

II Mio Grido (2010). Dir. Vito Alfarano. Screenshot.

I/ Mio Grido (2010),' a short screen project by Italian choreographer Vito Alfarano, has emerged from a series of movement and voice laboratories that involved the inmates of the Penitentiary Institution (Casa Circondariale) at Rovigo in North Italy. Positioning the audio-visual work in a broader frame that deals with the rehabilitation scheme of dance and performance arts in Italian prisons, Alfarano's // Mio Grido is in dialogue with internationally and socially engaged mediated choreographic practices such as Amie $S$. Dowling and Justin Forbord's film Well Contested Sites (2013) and viral videos that feature movement by the incarcerated. ${ }^{2}$ Abstraction, constructed narrative and video documentation provide the ways that the technology of the screen confronts the spectator with multi-racial and predominantly male bodies that inhabit forgotten and excluded spaces; places of social justice and discipline.

The movement and voice laboratory in Rovigo's Penitentiary that constitutes the material of I/ Mio Grido, has been realized from 2008-2010 under the support of the Italian Ministry of Justice. The incarcerated participated into a series of theatrical and The International Journal of Screendance 9 (2018).

(c) 2018 Mikou. This article is published under a Creative Commons Attribution 4.0 International License (https:/creativecommons.org/licenses/by/4.0/) 
movement-based laboratories that aimed to restore their self-estimation and helped them to reflect on themselves; processes that will eventually be useful for getting integrated into society upon their release from jail. Furthermore, the laboratory aimed to open the prisons to the City of Rovigo and to elaborate the Aristotelian idea of polis as a concept of an all-encompassing society that also embraces prisoners. Regarding the ethics of this initiative, performers were not obliged to participate in the artistic laboratories, but were free to choose the rules of participation. The outcomes of the laboratories include a dance performance inspired by Dante's Inferno, two books that document the artistic process, three film documentaries, a photo-exhibition, a videoinstallation with portraits of prisoners projected on the main walls of the city, and two videos: the aforementioned // Mio Grido and Peter Pan Syndrome.

II Mio Grido (My Shout) is an audio-visual work that sits closer to the genre of video art. Some occasional slow motion and speed adjustments, color correction and camera lens flares are the main video effects of the work. The short video begins with a series of medium shot portraits during which the eyes of the performers look directly to the camera and to the invisible spectator and potential judge. After the introduction, a stationary camera frames the upper bodies, feet and hand gestures of the naked inmates. A series of excerpts from the movement laboratory such as runs, exercises designed to build trust and support among the inmates and their free dances, constitute an integral audio-visual output. Prisoners are shown to have fun and to make fun of others like school children. Their movement often recalls animals, especially the ones trapped inside cages, and it is characterized by a humorous and light tone that gradually builds in tension and recalls the trauma of arrest. When a hand covers the camera lens, a series of screams emerge in correlation to extreme close-ups to open mouths that desperately try to release sorrow or regret. Micro-movements of breath and pulse, arm gestures as being arrested or slowly forming a punch as a symbol of lost power compose the additional movement vocabulary of the performers. Do the incarcerated still have courage and strength to survive the living conditions inside the prison?

Actions positioned in front of a white sterilized background disconnected from time and space is a consciously made artistic choice that aims to completely annul the surrounding environment of the prison in order to focus the gaze of the spectator on the individual mediated performers. The cell has been transformed into a white cube that helps to disassociate the bodies from their current social stigma. Screendance scholar Harmony Bench defines the white background as a no-place; "[a]bsent of spatial and political markers and relations, no-place is an anonymous, acontextual, blank space, often visualized on screen as a smooth, empty field of white or a black abyss in which dancers float." ${ }^{\prime 3}$ // Mio Grido challenges the notion of no-place by purposely erasing any architectural traces of the Penitentiary and the prison is paradoxically transformed into a paradise to be inhabited by angels without wings: guilty and innocent men. What 
remains if we remove prisoners from their cells and expose them naked in front of a white background? If place has been re-placed by an abstract and endless space and clothing is removed, what identifies them as prisoners and possibly as criminals?

The white no-place also creates a sharp contrast to the dark skin of some of the prisoners and it could potentially increase racialization. However, the camera keeps the same framing and proximity towards all the performers no matter their age, skin color or body type. Since the camera is static and avoids directing the attention of the viewer, the performers are the one who decide when to approach, look at, or perform for the lens. Furthermore, a fast cut between frames in the editing process does not allow any prioritization of the performers either. All of them, no matter their external characteristics, are equally guilty and evenly innocent. This becomes clearer as the clip of the sliding hands by two people of different skin color is often repeated. In the middle and towards the end of the video, two hands, one of dark skin and the other of white, slide towards opposite directions and reveal the empty white no-place; a spatial void that could reflect the abyss of their residing place and their souls. It is only at the end of the video when it is revealed that the performance takes places inside a prison, and so the white no-place in relationship to the static camera and the fast edits between the clips cannot be necessarily associated to techniques for increasing racial discrimination or attaching racial attributes to criminality. The camera attempts to maintain objectivity with these filmic tactics, yet objectivity is impossible since the white no-place makes the different skin colors among the prisoners even more apparent.

Exposed skin color, marks, texture, and different body types compose a male and mixed raced landscape full of homoeroticism and fragility. The performers of this participatory project are anonymous and their identity remains protected until the video credits reveal that the project took place in Rovigo's Penitentiary. White no-place, naked bodies and anonymity are artistic choices that aim to eliminate any prejudice against the performers and to lend to the spectators a new pair of eyes that helps them to distance the male performers from the context of the prison. These tactics can eventually help the incarcerated to restore their social image and convince the public opinion that they are not monsters ${ }^{4}$ or as said in their own words: "when you go out, let them know that we are not monsters."

This film's audience is invited to look beyond the artistic product and to reflect on the dynamics that dance has managed to activate and the conflicts that it has managed to resolve. Penitentiary institutions are places, which emerge from conflicts where clash, dispute and tension continue to grow. Prisons, at least in this video's context, are diverse and precarious environments that mirror problems and failures in their respective societies; places that are socially excluded and yet formed by micro-communities that deal with internal and external conflicts. Dance as an art that encourages socialization and a supposed freedom of expression through processes of self-reflection and care has a lot to offer in places of social justice and discipline where criminality lurks and 
oppression is present. When the screen disseminates this dance that takes place in this prison, then a discourse may be mobilized around penitentiary institutions and the conditions of mass incarceration. Hopefully, projects such as /I Mio Gridowill succeed to inspire new and inclusive perspectives in dance and screendance that bridge social imbalances and social justice and may help to bring change inside places of conflict. Movement oriented rehabilitation schemes may benefit the penitentiary system, but also help enrich dance and by extension screendance.

This review positions Alfarano's work together with promising artistic practices that embed choreographically driven and screen-based activism. // Mio Grido has already been screened in several Italian and international festivals of contemporary art, video art, videodance and dance on film. I came across Alfarano's work when it was submitted to [SET.mefree] Dance \& Movement on the Screen, a recently founded nomadic microfestival of screendance. // Mio Grido can be viewed in full here: https://vimeo.com/66759731.

\section{Biography}

Ariadne Mikou is an interdisciplinary dance artist, movement educator and emergent scholar from Greece. In 2017, she completed her PhD thesis entitled Choreographing Events: Demolition, Trace and Encounteras part of her fully-funded practice-as-research $\mathrm{PhD}$ at the University of Roehampton (UK). Her research interests focus on the spatiocorporeal and social intersections of event-oriented artistic practices that include architecture, choreography and the moving-image. In parallel to curating exchanges between artists through the art collective futuremellon/not yet art, her practice includes making and writing about works created for the screen, installations and mediated performances. Her writings have been published in the International Journal of Screendance and CHOROS International Dance Journal. Her forthcoming publications include a chapter in the book Performing Process: Sharing Dance and Choreographic Practice to be published by Intellect Books.

Email: mikoua@roehampton.ac.uk

Websites: www.amikou.com; www.futuremellon.com 


\section{Notes}

${ }^{1} / /$ Mio Grido is part of Oltre I Confini (Beyond the Boundaries), an overarching project that is also initiated by Alfarano and it helps to provide tools to incarcerated for socialization through theatre, movement and music. Specifically referring to the geopolitical area of Italy, the project Oltre I Confini is in dialogue with the national rehabilitation scheme Teatro in Carcere (the National Theatre in Prison coordination) and it derives from other initiatives such as the Compagnia della Fortezza that is a theatre company with a longstanding experience in social projects inside prisons and it dates back to 1988 .

${ }^{2}$ For instance, the viral video that featured detained of the Cebu Provincial Detention and Rehabilitation Center performing a series of dancing routines on Michael Jackson's Thriller.

${ }^{3}$ Bench, 53.

${ }^{4}$ The inmates of Rovigo's Penitentiary addressed the request that 'when you go out, let them know that we are not monsters.' This phrase was used by Alfarano as the title for the backstage video that emerged from the movement and voice laboratories.

\section{References}

Bench, Harmony. "Anti-Gravitational Choreographies: Strategies of Mobility in Screendance." The International Journal of Screendance 1 (2010): 53-61.

https://doi.org/10.18061/ijsd.v1i0.6138

Compagnia della Fortezza. Accessed 15 Dec. 2017. www.compagniadellafortezza.org/new

Teatro Carcere. Accessed 15 Dec. 2017. www.teatrocarcere.it 